\title{
REVIEW OF POLISH CONTRIBUTION TO SNOW COVER RESEARCH (1880-2017)
}

\author{
MaŁgorzata Falarz ${ }^{1}$, Marek Nowosad ${ }^{2}$, Ewa Bednorz ${ }^{3}$, SirPa Rasmus ${ }^{4}$ \\ ${ }^{1}$ Faculty of Earth Sciences, University of Silesia, Sosnowiec, Poland \\ ${ }^{2}$ Meteorology and Climatology Department, Maria Curie-Skłodowska University, Lublin, Poland \\ ${ }^{3}$ Department of Climatology, Adam Mickiewicz University in Poznań, Poland \\ ${ }^{4}$ Arctic Centre, University of Lapland, Rovaniemi, Finland
}

Manuscript received: October 2, 2017

Revised version: January 23, 2018

\begin{abstract}
Falarz M., Nowosad M., Bednorz E., Rasmus S., 2018. Review of Polish contribution to snow cover research (1880-2017). Quaestiones Geographicae 37(1), Bogucki Wydawnictwo Naukowe, Poznań, pp. 7-22, 2 figs.

ABSTRACT: The purpose of this article is to present the development of multifaceted research on snow cover conducted by Polish researchers in various parts of the world since the end of the $19^{\text {th }}$ century up to the modern times. The paper describes Polish studies on physical and chemical properties of snow cover, its long-term changes, relationships between snow cover and climate, impact of snow cover on environmental conditions and human activity. This work is also an attempt to show the contribution of Polish snow-related research to the international achievements in this fields.
\end{abstract}

KEY WORDS: snow cover, Polish research, climate

Corresponding author: Matgorzata Falarz, malgorzata.falarz@us.edu.pl

\section{Introduction, scope and purpose of the paper}

Regular measurements and observations of snow cover were initiated in the network of meteorological stations across Poland as late as in the 1920s. However, the interest in characteristics of this easily measurable climate element made researchers examine the snow cover in various measurement points as early as in the second half of the $19^{\text {th }}$ century (Wróblewski 1893, Satke 1899). The purpose of this article is to present the development of multifaceted research on snow cover conducted by Polish researchers (mainly geographers) in various parts of the world since the end of the $19^{\text {th }}$ century up to the modern times. This work is also an attempt to show the contribution of Polish snow-related research to the international achievements in this fields.

The bibliography of works of Polish researchers in Polish, English, German, French and Russian (scientific articles, monographs, chapters in monographs), whose leading subject is snow cover, amount nearly to 400 items. Due to space constraints of this article, less than a half of them were used herein and mainly studies containing a phrase "snow cover" (or Polish "pokrywa śnieżna") in title (excluding the oldest papers) were considered. The first works published fully in languages other than Polish were as follows: an article by Kosiba (1954) in English and a work by Michna and Paczos (1971) in German. The oldest work, which can be found in the Web of Science, is that by Sztyler (1989) published in the Aerosol 


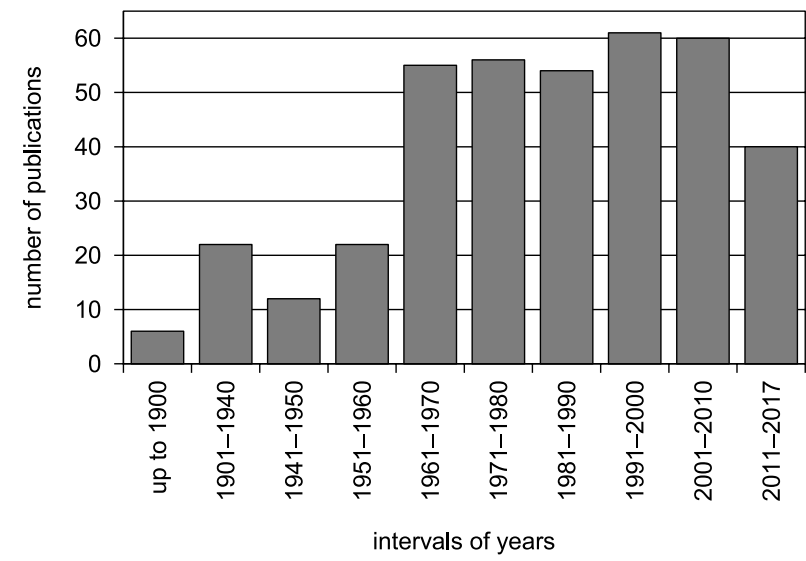

Fig. 1. Number of publications whose main subject was snow cover (1880-2017).

Science. In the decades after the Second World War, the number of publications on the subject of snow cover was increasing systematically until the end of the $20^{\text {th }}$ century. Subsequently, it remains constant, with concurrent increase in the number of publications which were included in the Web of Science data base (Fig. 1).

Brief references to snow-related research results obtained earlier on are found in almost all works on snow cover by Polish researchers. There are, however, a few articles in the Polish literature devoted fully to results of numerous studies on snow cover (Leszczycki 1931, Kędzia 1999, Juraszek-Wiewióra 2005, Cichała-Kamrowska et al. 2011). This article presents the territorial scope of snow-related research carried out by Polish researchers, the description of works written before the Second World War and the characteristic of later works with division into main directions of research on snow cover.

\section{Territorial scope of research on snow cover}

The majority of studies on snow cover authored by Polish researchers are based on daily, ground-level measurements of depth of snow cover conducted in points of the measurement network of the World Meteorological Organization which also owns stations and posts of the Polish Institute of Meteorology and Water Management. The spatial extent of these studies is varied and includes analyses employing a point scale or a meso- and macroregional scale. Studies employing the point scale are often based on long measurement series and concern variability and trends of changes in the occurrence of snow cover as well as classification of winters by snowiness (i.e. Trepińska 1973, Chrzanowski 1989, Falarz 1998, 2007a, Bartoszek 2007). Numerous early studies employing the regional scale present the basic characteristics of occurrence of snow cover in terms of space (e.g. Kosiba 1949, Dylewska 1961, Lorenc 1964, Michna, Paczos 1978, Leśniak 1981). Later studies concern solutions of specific research problems, e.g. the temporal and spatial structure of occurrence of snow cover in Pomerania (Czarnecka 1986) or the circulation conditions of snow cover in northwestern Poland (Bednorz 2001, 2002). Amongst the regional studies, the most numerous ones concern the occurrence of snow cover in mountainous areas.

The especially valuable studies are those which take into account entire Poland and present comprehensively and exhaustively the spatial structure of occurrence of snow cover as well its intraand interseasonal variability. Paczos $(1982,1985)$ described the basic characteristics of snow cover for the whole area of Poland and also put forward a classification of winter seasons by snowiness and assessed the impact of atmospheric circulation on the level of severity and snowiness of winters. The most comprehensive description of snow conditions in Poland was included in publications by Falarz (among others: 2004, 2007b, 2013) where multiannual changes and variability of occurrence of snow cover had been analysed in relation to circulation changes and where the impact of atmospheric circulation on the number of days with snow cover, its depth and stability had been investigated in detail. Czarnecka (2011, 2012) presented the temporal and spatial structure of occurrence of snow cover of different depth in Poland and demonstrated weak and statistically non-significant trends of changes. Similar type of analysis was done also by Szwed et al. (2017). Research on a wider regional scale, concerning the impact of atmospheric circulation on intraseasonal variability of snow cover in Central Europe, was conducted by Bednorz (2006, 2008a, 2008c, 2009a, 2011 among others).

Polish climatologists participate in programs whose results are studies on an international scale, e.g. analysis of snow conditions in the region of the Baltic Sea (Heino et al. 2008, Rasmus et al. 2015) or characteristic of multiannual variability 
of snow cover in the Western Carpathians (Falarz et al. 1998). Considerable climatic importance of snow in the polar regions inclines one to conduct research on its occurrence in high geographical latitudes as well as on its interaction with other atmospheric and environmental factors, e.g. morphology of a terrain or depth of the permafrost (Gonera, Rachlewicz 1997, Dolnicki 2002, Przybylak 2003, Zwoliński, 2007, Bednorz, Wibig 2016). Many of them concern the physicochemical parameters of snow in the Arctic (Leszkiewicz, Pulina 1999, Głowacki, Pulina 2000, Stachnik, Uzarowicz 2011, Nawrot et al. 2016). In the 21 century research on accumulation, metamorphism and melting of snow cover on Svalbard glaciers was developed detaily by Grabiec (2005), Grabiec et al. (2006), Laska et al. (2016) and Sobota (2017). Regional research of Polish climatologists on the impact of atmospheric factors on the seasonal cycle of formation, presence and disappearance of snow cover extends to Eastern Europe, Siberia, the Pamirs and the Antarctic (Hess 1962, Bednorz 2004, 2016, Zwoliński 2007, Bednorz, Wibig 2008, 2016).

\section{Research on snow cover before the Second World War}

First descriptions of variability of snow cover persistence, drawn up by a Pole, can be attributed to Zapałowicz. In papers on the subject of flora, attention was paid, i.a. to the time of disappearance of snow in the massif of Babia Góra (Zapałowicz 1880) and in the Eastern Carpathians (Zapałowicz 1889). Research on algae, which change the colour of snow, were conducted in the Tatras in 1880 by Rostafiński (1927). As far as historical accounts are concerned, Romer (1892) wrote about snowfall in May, even mentioning chronicles from the $19^{\text {th }}$ century. Wróblewski (1893) described the characteristics of snow and its impact on the course of selected meteorological elements. Satke $(1896,1899)$ carried out daily measurements of snow cover in Tarnopol.

An extensive work on the persistence of snow cover, where data from 248 stations located in the northern part of the Carpathians and in the Carpathian Foothills had been used, was written by Kamińska (1912). Romer (1913) introduced the index of conservation of snow cover which was the ratio of the monthly sum of daily heights of snow cover and the monthly sum of height of new snow. A summary of selected snow-related characteristics in 31 stations was published by Merecki (1914).

In 1923 Dobrowolski (a, b) published monography Natural history of ice (in Polish Historja naturalna lodu) devoting two chapters to physical properties and description of snow cover. Soon Kosińska-Bartnicka (1924, 1925) followed and she characterised snow cover in Poland during a frosty and snowfall-rich winter of 1923/1924. Variability of snow cover in Poland during an exceptionally frosty, but also snowy, winter of 1928/1929 was analysed by Gumiński (1931).

An attempt at classification of the process of disappearance of snow cover and analysis of causes of uneven snowmelt was published by Ormicki (1929). In 1929, a geographical centre in Cracow started research, i.a. on snow cover in the Tatras (Smoleński 1932). In 1929, field measurements of variability of depth of snow cover in Roztochia and Volhynia were carried out (Czyżewski 1929).

Milata (1937b), using data from 306 stations, published a characteristic of snow cover in the Carpathians. This author stressed the impact the foehn on snow cover. In 1938, the Carpathian Commission on Snow and Avalanches was established in Cracow whose purpose was i.a. investigation of the amount of snow in the Carpathians, physical features of snow and impact of the topography, wind conditions and vegetation on snow cover (Milata 1938).

\section{Directions of research on snow cover after the Second World War}

\section{Basic characteristics of snow cover and research methodology}

Daily observations of snow cover consist mainly in measuring the depth with an accuracy of $1 \mathrm{~cm}$ once a day at 6:00 UTC; achievement of a depth of $\geq 1 \mathrm{~cm}$ for at least $50 \%$ of the observed area means a day with snow cover.

Satellite images are a source of information on snow cover (Feleksy-Bielak 1978). The area of a country or continent, where snow cover persists, is determined on their basis. Kotarba, on the Centre 
for Space Research portal, presents maps with the current extent of snow cover both in Poland and in Europe as well as graphs showing the percentage of the area of selected countries covered with snow on individual days of specific winters from the winter of 2004/ 2005 onwards (Kotarba 2017).

Nevertheless, values obtained from measurements at meteorological stations and posts still constitute the basis for calculation of the majority of statistics characterising the appearance of snow cover. The simplest one of them and, at the same time, the most frequently employed one is the number of days with snow cover in the winter season (Chrzanowski 1988). In the temperate zone, snow can be observed for a few months every year, but it is never a permanent winter phenomenon. Therefore, in the Polish studies, apart from the number of days with snow cover, which reflects its real duration, the potential snow cover persistence is often provided. This term was defined by Leśniak (1973) as the number of days between the first and the last occurrence of snow cover in the winter season, i.e. between the first and the last day with weather conditions allowing the formation or occurrence of snow cover. Falarz (2013) analysed the seasonal stability of snow cover which was defined as a percentage ratio of the real and the potential snow cover persistence in the winter season (an index firstly used by Leśniak (1981)). The number of days with snow cover exceeding arbitrarily accepted depth thresholds or the probability of exceeding selected measures of depth are also frequently analysed (e.g. Paczos 1982, Bednorz 2004, Falarz 2008, Kasprowicz 2010, Czarnecka 2012). The second group of measures of snowiness are parameters describing the depth of snow cover. The snowiness of a winter season is characterised most often by the mean and maximum depth of snow cover achieved during a given winter (e.g. Bednorz 2001, 2009, Falarz 2004, 2007b, Kasprowicz 2010). Furthermore, changes in snow cover depth from day to day were calculated as well (Nowosad 1992a; Bednorz 2006). As far as hydrological research is concerned, the key is the water content in snow, i.e. the amount of water obtained from melting a unit of volume of snow (e.g. Kwiatkowski 1978, Sadowski 1980).

The variety of purposes of research on snow cover conducted by Poles makes the range of methods employed very broad. Only some of them were mentioned in this article. Cartographic descriptions of snow cover were drawn up as early as in the first half of the $20^{\text {th }}$ century. Isolines, showing the average values of individual characteristics, were being gradually drawn up on the basis of ever longer observation series (e.g. including 30 winters - Paczos 1985; Bednorz 2001, 2002). Currently, maps are drawn up using GIS techniques (e.g. Kozyra 2005).

Formulae were created describing the dependence (usually linear) of various characteristics of snow cover on altitude. The most frequently calculated characteristic was the average number of days with snow cover during the winter (Kosiba 1948/49; Chomicz 1953; Madany 1961, Hess 1968; Leśniak 1973, 1980; Michna and Paczos 1976, Paczos 1977, 1985; Nowosad 1994).

Studies on snow cover employed various statistical methods - correlation (e.g. between snow density and selected meteorological elements - Kłapowa 1980; between characteristics of snow cover and both temperature and precipitation - Bednorz 2004), regressive relationships using the Fourier coefficients (Kozyra 2005) and the principal component analysis (Bednorz 2009; Falarz 2013). The Alexandersson test was used when checking the homogeneity snow cover series (Falarz 2000/2001, 2007, 2008). Furthermore, taxonomic methods were used when dividing an area into regions of occurrence of snow cover (Bednorz 2001, 2009). To determine exceptionally snowy winters or winters with little snow, the $90^{\text {th }}$ and the $10^{\text {th }}$ percentiles were used (Falarz 2008). Distributions of the maximum probability of water reserve in snow were determined and correlation functions of water reserve in snow cover were designed and used to determine the decreasing of correlations of water reserve between various points as a function of growing distance between them (Sadowski 1980).

Karzyński and Nodzyński (2005) created numerical models forecasting the level of avalanche hazard in mountainous areas. Chrustek et al. (2013) used LIDAR for obtaining snow avalanche information.

\section{Long-term changes and variability of snow cover}

Research on long-term changes and variability of snow cover started to develop in the last 
decade of the $20^{\text {th }}$ century. Most often, it concerned multiannual trends, but fluctuations and periodicity of changes were also studied. A downward trend of various characteristics of snow cover was detected, i.a. in northern Germany (Bednorz 2007), Eastern Europe (Bednorz, Kossowski 2004) and in most of Poland (Falarz 2004, Nowosad, Bartoszek 2007). A negative trend of snow cover conditions deepened considerably in the last three decades of the $20^{\text {th }}$ century and usually showed statistical significance in that period (Falarz et al. 1998, Falarz 2002b).

In Spitsbergen, a negative trend of the average depth of snow cover in 1979-2009 was observed; it was statistically significant in May and June (Niedźwiedź, Styszyńska 2013). Bednorz (2006) identified a downward trend of depth of snow cover in the lowlands of Germany and Poland in the third decade of December in 1971-2000. In the second half of the $20^{\text {th }}$ century, in entire Poland, except for the highest parts of the Sudety Mountains, persistence of snow cover was characterised by a small, negative trend, statistically significant in southern Poland only (Falarz 2010). Research on the impact of urban climate (with Cracow as an example) on the strength of the trend of snow cover indicated a larger decrease in values of snow-related characteristics in the city center compared with rural areas (Falarz 1998c). In periods longer than 50 years no significant trends of snow conditions were distinguished (Falarz 2002b, 2003).

A positive trend of snow-related conditions was observed in Poland in the second half of the $20^{\text {th }}$ century in areas with abundant snow cover, i.e. in the northeastern part of the country (in relation to the maximum snow cover depth) and in certain mountainous areas (in relation to the snow cover duration; Falarz 2004). In the same period, a positive trend of potential period of snow cover duration in most of Poland was detected as well. It was connected primarily with the ever earlier appearance of snow cover in the autumn (Falarz 2007c). A small, positive trend of the number of days with snow cover and the potential period of its presence in the whole high-altitude profile of Tatras in the second half of the $20^{\text {th }}$ century was found (Falarz 2000-2001).

In the first years of the $21^{\text {st }}$ century, the IPCC hypothesis concerning an increase in the frequency of extreme meteorological phenomena was examined in relation to the snow cover in
Poland (Falarz 2008). There was detected a slight decrease in the frequency of appearance of an extremely thick and long-persistent snow cover with concurrent increase in the frequency of occurrence of poor snow-related conditions since the early 1970s.

Interseasonal variability of snow cover increases in most of Poland in the second half of the $20^{\text {th }}$ century (Falarz 2004). There was pointed an approximately 8-year periodicity in non-mountainous areas of Poland (Falarz 2004) and a 3-4year periodicity in the Tatras (Falarz 2000-2001).

Some studies of multiannual changes in snow cover were inconclusive. Szwed et al. $(2016,2017)$ concluded that the obtained picture of changes for Poland and Potsdam was complex and difficult to interpret. The complexity of results is associated with the fact that Poland is located in the zone of the transitional temperate climate, where a large variability of climatic conditions is noted.

Polish snow researchers have contributed to international efforts too. In research on the variability of snow cover for 8 pairs of stations located at a similar altitude on the Polish and Slovak side of the Western Carpathians, statistically significant, positive correlation coefficients of longterm run of snow cover duration on the northern and southern slope of the Carpathians were obtained (Falarz et al. 1998). Two recent reports of the Baltic Assessment of Climate Change aimed at reviewing the state of knowledge concerning climate change and climate impacts within the Baltic Sea drainage basin. The report concluded that a recent decrease has been seen in snow cover duration, snow water equivalent and snow depth in the southwestern regions of the drainage basin, but an increase in the northeastern regions (Heino et al. 2008). Terrestrial cryosphere was discussed also in the BACC II - report, as part of a larger unit of climate change. In the chapter, recent and present changes in glacier extent and mass balance as well as in frozen ground were considered, but the majority of the reviewed research was on changes in the seasonal snow cover. The report concluded that a decrease in snow cover extent, duration and amount is seen observed within the drainage basin, although there is interannual and regional variations (Rasmus et al. 2015).

Gądek et al. (2016) analysed variability of the snow avalanche danger in the Tatra Mountains during the past nine decades. 


\section{Relationships between snow cover and atmospheric circulation}

The occurrence of snow cover in the temperate climatic zone is characterised by multiple episodes of its formation and disappearance which are associated with snowfall (sometimes heavy) and melting during the thaw. The dynamics of occurrence of snow cover in the winter is always connected with a change in atmospheric conditions, mainly temperature and precipitations, which are shaped primarily by the atmospheric circulation during the winter season. Thus, the question of the impact of macroscale and regional types of circulation on the occurrence of snow cover is one of the main aspects of research on this subject in the international climatology. Furthermore, it has also long been the subject of inquiries of Polish researchers. Milata (1938) analysed the quality of winters, including the intensity of snowfall in terms of pressure patterns over Europe. Niedźwiedź (1981) studied the influence of synoptic situations on the dynamics of snow cover in the upper Vistula river basin. Since then, it has become obvious that snowy winters in Poland are usually connected with high frequency of the northern and eastern airflows, while the western and southern advection contributes to mild and less snowy winters. The variability between cyclonic or anticyclonic character of pressure patterns seems to have less impact on snow cover occurrence (Paczos 1982, Chrzanowski 1989). Different results were obtained by Nowosad (1992) who had analysed the daily changes in the snow cover depth as a function of atmospheric circulation types in the Bieszczady Mountains. He found out that in the mountainous southeastern Poland the western and northwestern cyclonic types of circulation cause snowfall most frequently, while eastern anticyclonic types are favorable to snow cover persistence.

The North Atlantic Oscillation (NAO) is a macroscale circulation pattern most often used to explain the variability of different meteorological factors in Europe, including snow cover. Falarz (2007b) found out that the NAO determines snow cover duration in winter (December-March) in $45-55 \%$ over the vast area of the Polish lowlands. Bednorz (2004, 2008b, 2009a) delimited the spatial extent of the NAO influence on winter snowiness in Europe and found out that the correlation between the duration of snow cover and the NAO index was strong and statistically significant only in central Europe, but it disappears to the east of $30^{\circ}$ E. Other than NAO macroscale circulation patterns of lower frequency do not influence significantly winter snowiness in central Europe, however they govern fluctuations in snow cover depth in eastern and northeastern part of the continent. In reference to NAO influence on winter and weather conditions in Poland Falarz (2009) performed the detail analysis of the strength and position of the NAO centers of action, and she discovered that changes of sea level pressure in the Icelandic Low and the longitude of the Azores High in January explain about $40 \%$ of the temperature and snow cover variability in Poland.

Concerning the intra-annual variability of snow cover occurrence in central Europe which is always governed by synoptic conditions, numerous studies pertained to daily-time scale analysis of weather patterns related to occurrence of snowfall and snowmelt in Europe. Bednorz (2011) proved that the negative anomalies of sea level pressure and the $500 \mathrm{hPa}$ geopotential height were responsible for heavy snowfalls in the central European lowlands. On the other hand, the preservation of snow cover in the central European lowlands is possible under the positive pressure anomalies over most of the continent. The last stages of the intra-annual cycles of snow cover occurrence, which may recur several times during the cold season, are the thaws. Numerous studies of Polish researches addressed atmospheric conditions of mid-winter and spring snowmelt and its hydrological implications (i.e. Mrugała 1987, Kupczyk 1997, Bednorz 2006, 2009b). Similar studies, concerning synoptic conditions of the annual cycle of snow cover formation, persistence and disappearance, were performed for vast areas of the Antarctic (Zwoliński 2007), the Arctic (Luks et al. 2011) and Siberia (Bednorz 2016, Bednorz, Wibig 2016).

\section{Relationships between snow cover and other climatic elements}

After the Second World War developed the research on the 'snow cover - other climate elements' interactions. There was investigated among others the strength of relationships 
between snow cover and solar radiation (Hess 1962), air temperature (e.g. Leśniak 1986), ground temperature (Gądek, Leszkiewicz 2010) and ocean surface temperature (Falarz, Marsz 2005), precipitation, including the total precipitation (e.g. Bednorz 2004) as well as division into solid (e.g. Piotrowicz 1996) and liquid (e.g. Nowosad 1993b) precipitation.

In his research on the Fedchenko Glacier in 1962, Hess analysed thoroughly the differences in radiation balance over the snow cover and ground not covered with snow as a function of the extent of cloud cover.

The most extensive research was conducted within the scope of the 'snow cover - air temperature' relationship. Hess (1962) determined the magnitude of the cooling influence of snow cover on the temperature of air lingering above it, proving that the air temperature over the area covered with snow was lower by $7^{\circ} \mathrm{C}$ than that over the area without snow. He also found a very close relationship between the mean annual number of days with snow cover and the average annual temperature in the Western Carpathians, concluding that a decrease in the annual temperature by $1{ }^{\circ} \mathrm{C}$ was accompanied by 20 more days with snow cover per year (Hess 1965). In research conducted across Poland, Paczos (1982) calculated the correlation coefficient between the average snowiness index of winters for the whole country and the average thermal severity index of winters, proving that winters of low air temperature are usually very snowy. In 1986, Leśniak examined the impact of air temperature below threshold values of $0^{\circ} \mathrm{C}$ and $5^{\circ} \mathrm{C}$ on the frequency of occurrence of snow cover in the Western Carpathians. According her results the end of occurrence of snow cover in the winter season was associated with passage of the daily maximum temperature above a threshold of $5^{\circ} \mathrm{C}$; this threshold determining the end of the snowfall season at the same time. Piotrowicz (1996) demonstrated a strong correlation between the number of days with snow cover in Krakow and the number of winter days and frosty days. The dependence of snow cover duration on air temperature for individual months of the winter season in Poznan was examined by Bednorz (2000), indicating the closest relationship in February.

Gądek and Leszkiewicz (2010) investigated the relationship between air temperature, snow cover and its basal temperature in the Tatras. Interseasonal changes of ground surface temperature in the winter may be related to changes in snow cover depth and air temperature both in the period with and without snow cover. The contemporary cryosphere in the Tatras is very sensitive to the air temperature changes in winter (Gądek 2014).

Snow cover in Poland turns out to be also significantly correlated with the temperature of surface of certain areas of the Atlantic (Falarz, Marsz 2005). The duration of snow cover in Poland is a reaction to the surface temperature of the Atlantic observed a few months before a winter season.

In certain studies, the magnitude of impact of temperature and snowfall or total precipitation on snow cover was compared. Falarz (2002a) pointed out that a long-term variability of snow cover was most sensitive to snowfall changes across the entire vertical profile of the Polish Tatras. The second factor influencing snow-related conditions in that area was the air temperature. Bednorz (2004) investigated snow cover occurrence in Eastern Europe, discovering a strong, positive correlation between the annual number of days with snow cover and the number of days with mean temperature $<0^{\circ} \mathrm{C}$ for most parts of the study area. However, a positive correlation between snow depth and precipitation was significant only in southern areas of Eastern Europe and in areas with permanent snow cover.

In studies of relationships of snow cover with snowfall, Nowosad (1993a) concluded that days with solid precipitation were accompanied by an increase in snow cover depth in $50 \%$ of the cases only. On the other hand, there was a decrease in snow cover depth in $83 \%$ days with rainfall (Nowosad 1993b).

Zwoliński (2007) used the thickness of the snow cover to classify weather types and by grouping them, determined seasons of mineral matter mobility in paraglacial areas of the King George Island in South Shetland Islands.

\section{Physical and chemical properties of snow cover}

Since the beginning of snow cover investigations researchers have been interested in physical properties of snow. Hence, they studied the following: temperature of snow cover (e.g. 
Bednarek et al. 1979), the snow water equivalent (e.g. Głowacki, Pulina 2000), thermal conductivity (e.g. Kłapowa 1980b), density of snow (e.g. Kwiatkowski 1978), water reserve in snow cover (e.g. Lewińska 1963), evaporation and sublimation of snow cover (e.g. Szkutnicki 1978), thawing (e.g. Kłapowie 1967, Kłapa 1968) and snow albedo (e.g. Sztyler 1989).

The distribution of temperature in vertical profile of snow cover in various areas was analysed by, among others, Hess (1962) and Kłapowa (1980a, b). Hess (1962), conducting research on the Fedchenko Glacier in the Pamirs, determined the differences between snow surface temperature and air temperature as well as between snow surface temperature and temperature of ground without snow cover. Kłapowa (1980a) proved a delayed reaction of the thermal conditions deep in snow cover to changes in the thermal conditions of air. In the same year (1980b), she published the results of large-scale research in Hala Gąsienicowa in the Tatras on metamorphosis of snow as a function of atmospheric conditions and land relief. As a result, she determined, i.a. the relationships between snow temperature/ depth and air temperature. Baranowski (1977, 1979) described mass movements and downhill creep of snow cover.

Gądek and Kędzia (2006, 2009) as well as Gądek and Leszkiewicz (2010) carried out measurements of temperature at the bottom of snow cover in order to examine the features of the permafrost in the Tatras. They demonstrated that the contemporary perennial permafrost in the alpine zone of the Tatras was developing both under thin and thick snow cover, and its existence may have been connected with the local air circulation.

Snow density differentiation as a function of action of other climatic elements on slopes of various exposure was investigated by Rajwa (1965) on Kasprowy Wierch, concluding that the largest role in snow density variability was played by wind in the first half of the winter season, and sunshine in the second one. Kwiatkowski (1978) examined the amount of water reserve in the snow cover in hypsometric zones of the Polish Sudety Mountains. Sadowski (1980), taking into account selected characteristics of water reserve in snow cover, distinguished 9 snow regions in Poland. Moreover, he questioned the standard of snow loads in Poland, which was prevailing at the time, as underestimated in relation to the actually occurring loads. On the other hand, Sztyler (1989) examined the impact of air pollution on snow cover albedo in an industrialised area (Katowice).

Research on chemical properties of snow cover was conducted as early as in the 1980s (e.g. Lenart, Nowicki 1984), but its considerable development took place in the $21^{\text {st }}$ century. The most frequently was analysed $\mathrm{pH}$ of snow cover (e.g. Nawrot et al. 2016), snow conductivity (e.g. Zwoliński 2007, Kasina 2008) as well as positive and negative ion content (e.g. Głowacki, Pulina 2000, Zwoliński 2007). Many of those studies were carried out in polar areas: in the vertical profile of the Hans Glacier (Spitsbergen; Nawrot et al. 2016), on the Obruchev Glacier (the Ural Mountains, Russia; Stachnik and Uzarowicz 2011) and on King George Island (the Antarctic; Zwoliński 2007).

However, the chemical properties of snow cover in terms of its changes associated with anthropogenic activity were often investigated (e.g. Polkowska et al. 2010, Kozłowski et al. 2012). Results of all studies demonstrate changes in natural features of snow cover under the influence of various human activities, reflected by an increase in the amount of anthropogenic substances: suspended solids, hydrocarbons, heavy metals, biogenic compounds, bacteriological contamination and others (Kasina 2008, Ociepa et al. 2015, Siudek et al. 2015).

\section{Impact of snow cover on environmental conditions and human activity}

Snow cover is an important factor responsible for shaping water resources in the ground (Kosiba 1957). Kupczyk (1980) proposed a way of forecasting the thaw-related supply of a river drainage basin and applied it to a simulation of drainage in the upper part of the drainage basin of the Dunajec River.

Teisseyre (1979) noticed that sliding snowdrifts damage the ground, especially when the terrain is considerably inclined. A generalisation may be found in the results of work of Kłapa (1980) who wrote that a thick snow cover generally decreased the activity of morphological processes of the ground. Snow cover interacts with 
the anthropogenic changes in the environment (increased erosion, degradation of plant cover, levelling of slope gradients). This applies to areas intended to be pistes. Research carried out by Łajczak (2006) showed a relationship according which the magnitude of these changes was a function of snow cover depth. Krzesiwo (2015) gave information that snowmaking "contributes to shortening of the vegetation period, quantitative and qualitative changes in the composition of the flora of mountainous meadows and pastures, disturbance of water balance and soil contamination as a result of the use of chemical agents".

Despite that snow cover hinders deep soil freezing, a negative effect of a thick and long-lasting snow cover on vegetation of winter crop and efficiency of sowing was pointed out (e.g. Kosińska-Bartnicka 1924, 1925, Gumiński 1947, Molga 1949). Among others, Michałowski (1962), Klein (1967) and Jurzecki (1969) also wrote about the impact of snow cover on plants. Mutual relationships between snow cover and vegetation in broadleaved forests in the Białowieski National Park were the subject of a dissertation by Żarnowiecki (2008). Kępski et al. (2017) correlated spatial information on tundra vegetation and snow cover in southern Svalbard using images collected from camera. Kozłowska and Rączkowska (2006) investigated influence of depth and duration of snow patches in Tatras on different plant species.

Sadowski (1980) wrote about the negative impact of snow cover on the construction industry. Interruptions in railway services caused by snow cover were analysed by Rajca (1964). Among others, Dylewska (1964) as well as Łopata and Warakomski (1977) focused on the occurrence of snowstorms and blizzards.

Research was carried out on the life of hoofed mammals during persistence of snow cover and its impact on their survival in Puszcza Białowieska (Jędrzejewski et al. 1992; Okarma et al. 1995). Research on the impact of snow cover on populations of wild boars (Kanzaki et al. 1998) and wolves (Gula 2004) were also conducted in the Bieszczady Mountains.

Attention was focused on the beneficial influence of persistent snow cover in terms of the impact on the state of health and mental sphere of a human (e.g. Bogucki et al. 1972). A natural snow cover was necessary for skiing before the introduction of "snow cannons". Snow cover in terms of skiing was analysed as early as in the 1930s (Milata 1937). To assess snow-related conditions, it was often the case that characteristics of snow cover with height exceeding a certain threshold were taken into account, e.g. Łobożewicz 1970, 1979; Michna and Paczos 1971a, b, 1976; Bogucki et al. 1972; Kwiatkowski and Lucerski 1979a, b; Nowosad 1980; Kwiatkowski 1983; Sarna 2000). When assessing skiing conditions in the individual parts of winters, a key role was attributed to snow cover (e.g. Kwiatkowski, Lucerski 1979b, Nowosad 1980/1981). Quality classifications of snow conditions were proposed (Michna and Paczos 1976) as well as classifications of meteorological conditions focusing on snow cover depth (Nowosad 1980), in terms of skiing needs. Krzesiwo (2015), analysing economic aspects of ski resorts, noticed that the socalled 'snow reliability' was needed, i.e. maintenance of snow cover with a depth of $>30 \mathrm{~cm}$ for at least a 100 days a season.

Milata (1947) wrote about the avalanche hazard and ways of conduct when faced with it. Apart from danger to humans and animals, avalanches transform the vegetation (Lempa et al. 2014, 2016, Czajka et al. 2015, Spyt et al. 2016). Myczkowski $(1956,1962)$ described the impact of avalanches in the Tatras on dwarf mountain pines and dense forest stands. The influence of avalanches on terrain and vegetation was one of the subjects of study by Rączkowska et al. (2015). Examples of changes in the upper limit of forest in the area around Biały Żleb in the High Tatras were described by Kaczka et al. (2015).

\section{Summary}

A wide scope of research on snow cover and good achievements of Polish researchers in this field ensure strong interest on them amongst Polish and foreign climatologists. A commonly used measure of scientific success are bibliometric parameters. There are 33 publications in the Web of Science (access on July 2017) by Polish authors with the phrase "snow cover" in the title ( $16^{\text {th }}$ place in the world, $10^{\text {th }}$ in Europe), having the h-index of 10, with the total number of citations of 413. Growing activity and importance of Polish snow cover researchers internationally 


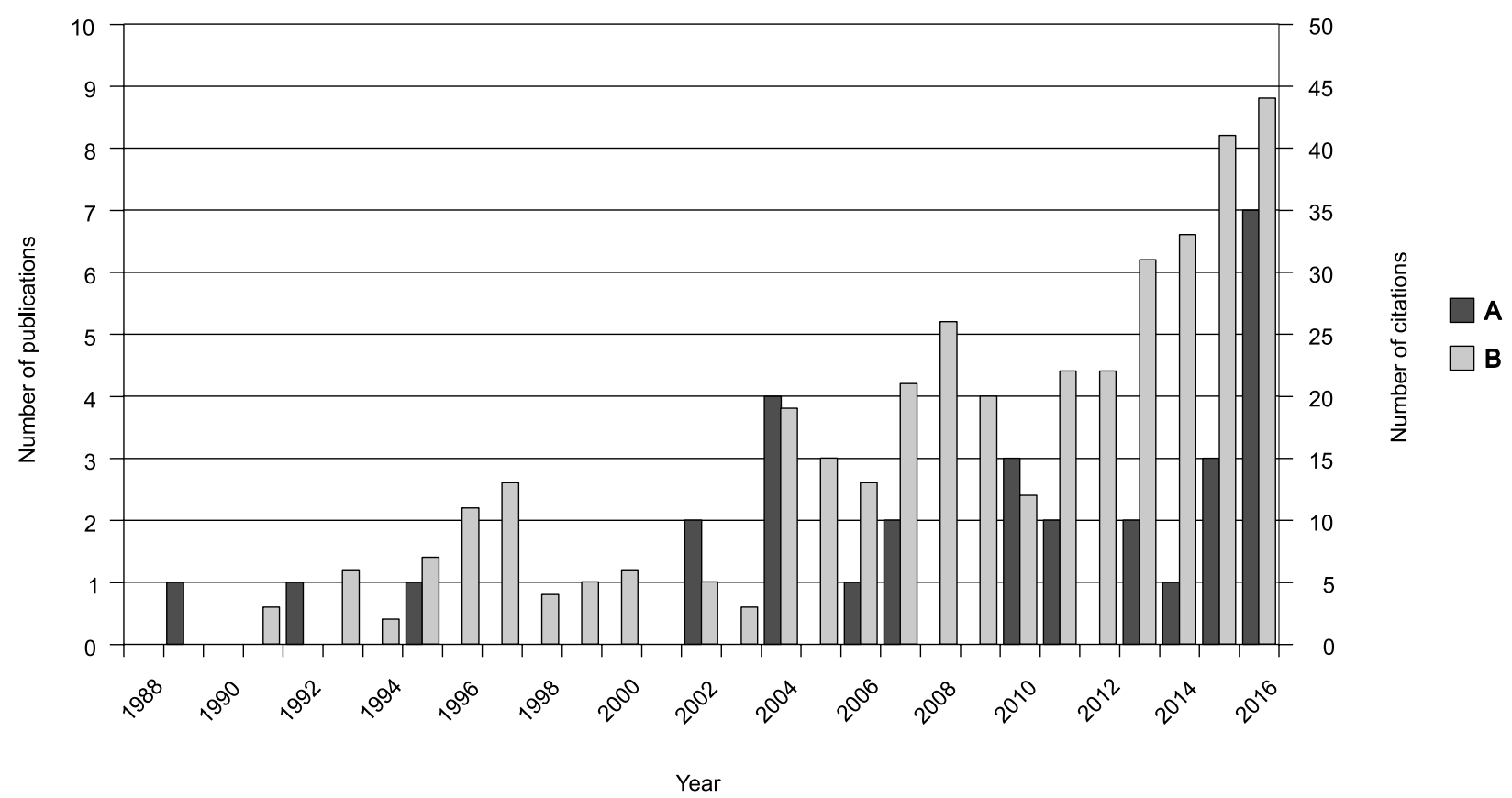

Fig. 2. Number of publications by Polish authors whose titles include the phrase "snow cover" (A) and number of citations of these publications in each year (B) according to the Web of Science (access on 24 July 2017).

draws one's attention, especially after 2000, which is reflected in increasingly larger number of publications and citations listed in international scientific databases (Fig. 2).

Out of 33 articles indexed in the Web of Science, the oldest publications on the impact of snow cover on environmental conditions enjoy the highest interest, reflected in the largest number of citations (Jędrzejewski et al. 1992, Okarma et al. 1995 - number of citations above 60). As snow cover is both an indicator and a stimulator of climate change, publications of purely climatological nature concerning multiannual changes in snow cover parameters and studies taking into account the impact of macroscale circulation conditions on snowiness of winters are also frequently cited (Bednorz 2002, 2004, Falarz 2004 - number of citations of each one above 30). Theses on snow cover, written to obtain an academic degree from, i.a. the following universities: Maria Skłodowska-Curie University in Lublin, Adam Mickiewicz University in Poznań, the Jagiellonian University and the University of Silesia, indicate large importance of issues connected with snow cover and interests within the Polish climatologic environment.

The most important achievements of Polish researchers within the scope of snow-related investigations are as follows:
- knowledge of the characteristics of temperature and density distribution in a vertical profile of snow cover and examination of the impact of human activity on chemical properties of snow;

- determination of multiannual trends of snow cover in the Baltic Sea Basin and in the Carpathians as part of international cooperation;

- determination of macroscale and regional circulation conditions of the annual cycle of snow cover formation, persistence and disappearance, performed for the area of Poland, central Europe and vast areas of Siberia and the Arctic;

- determination of the magnitude of air cooling over snow cover, investigation of relationships of snow cover with air temperature and precipitation in Poland and Eastern Europe;

- creation of models defining the role of snow cover in drainage, conducting research on the impact of snow cover on agriculture and construction industry as well as determination of temporal and spatial variability of snow-related conditions in terms of skiing;

- growing spatial extent of research on snow cover conducted by Polish climatologists associated with ever easier access to databases and use of modern techniques of data compilation; 
- use of state of the art methods concerning both collection of information on snow cover and its subsequent statistical analysis;

- wide scope of research, growing activity and ever greater importance of Polish snow cover researchers internationally, reflected in increasingly larger number of publications and citations listed in international scientific databases. Internationally acclaimed, important achievements of Polish climatologists in research on snow cover and dynamic development bode well to the further progress of this dicipline in Poland. Objectives and challenges in the domain of research on snow cover are numerous and involve, i.a. wider application of modern measuring techniques and measurement data (e.g. global data from satellite images) as well as attempts to carry out a synthetic analysis on a continental (for Europe) and global scale, using the existing methods and experience.

\section{References}

Baranowski S., 1977. Próba ilościowej oceny powolnych ruchów masowych w pokrywie śnieżnej. Materiaty Badawcze IMGW, Meteorologia: 165-175.

Baranowski S., 1979. Procesy osiadania i spełzywania pokrywy śnieżnej w Sudetach. Problemy Zagospodarowania Ziem Górskich 20: 57-71.

Bartoszek K., 2007. Charakterystyka pokrywy śnieżnej w Obserwatorium Agrometeorologicznym w Felinie (1955/1956-2004/2005). Annales UMCS, sec. E LXII, 1: 39-47.

Bednarek H., Kołodziej J., Liniewicz K, 1979. Charakterystyka termiki powietrza i szaty śnieżnej w chłodnej porze roku na Lubelszczyźnie (1950/51-1969/70). Biuletyn Lubelskiego Towarzystwa Naukowego 21, Geografia 2: 75-81.

Bednorz E., 2000. Snow, temperature and precipitation conditions of winters in Poznań in relation to the Wolf numbers, Prace Geograficzne UJ 108: 13-18.

Bednorz E., 2001. Pokrywa śnieżna a kierunki naptywu mas powietrza w Polsce Pótnocno-Zachodniej, Wydawnictwo Naukowe Uniwersytetu A. Mickiewicza, Poznań.

Bednorz E., 2002. Snow cover in western Poland and macro-scale circulation conditions. International Journal of Climatology 22(5): 533-541.

Bednorz E., 2004. Snow cover in eastern Europe in relation to temperature, precipitation and circulation. International Journal of Climatology 24(5): 591-601. DOI: 10.1002/ joc.1014.

Bednorz E., 2006. A White Christmas or a Christmas Thaw? - Changes in snow cover depth in German-Polish lowlands during the last decade of December against daily circulation patterns. Meteorologische Zeitschrift 15(6): 579583. DOI: 10.1127/0941-2948/2006/0165.

Bednorz E., 2007. Zmiany występowania pokrywy śnieżnej w północnych Niemczech w latach 1950/51-1999/00. In: K. Piotrowicz, R. Twardosz (eds), Wahania klimatu w różnych skalach przestrzennych i czasowych, IGiGP UJ, Kraków: 215-223.

Bednorz E., 2008a. Synoptic conditions of snow occurrence in Budapest. Meteorologische Zeitschrift 17(1): 39-45.

Bednorz E., 2008b. Fluctuations of snow cover depth in Central European Lowlands under Northern Hemisphere circulation patterns. Quaestiones Geographicae 27A: 5-18.

Bednorz E., 2008c. Synoptic reasons for heavy snowfalls in the Polish - German lowlands. Theoretical and Applied Climatology 92: 133-140. DOI: 10.1007/ s00704-007-0322-4.

Bednorz E., 2009a. Wptyw sytuacji barycznych na występowanie pokrywy śnieżnej na obszarach nizinnych środkowej Europy. Wydawnictwo Naukowe UAM, Seria Geografia: 82.

Bednorz E., 2009b. Synoptic conditions for rapid snowmelt in the Polish - German lowlands. Theoretical and Applied Climatology 97: 279-286. , DOI: 10.1007/ s00704-008-0063-z.

Bednorz E., 2011. Synoptic conditions of the occurrence of snow cover in central European lowlands. International Journal of Climatology 31(8): 1108-1118. DOI: 10.1002/ joc. 2130 .

Bednorz E., 2016. Seasonal cycle of snow cover changes in Eastern Siberia and its synoptic preconditions. Russian Meteorology and Hydrology 41(9): 648-656. DOI: 10.3103/ S1068373916090089.

Bednorz E., Kossowski T., 2004. Long-term changes in snow cover depth in eastern Europe. Climate Research 27(3): 231-236.

Bednorz E., Wibig J., 2008. Snow depth in eastern Europe in relation to circulation patterns. Annals of Glaciology 48: 135-149.

Bednorz E., Wibig J., 2016. Spatial distribution and synoptic conditions of snow accumulation in the Russian Arctic. Polar Research 35: 25916. DOI: org/10.3402/polar. v35.25916.

Bogucki J., Kowal Z., Ziókowski F., 1972. Warunki środowiskowe okolic Zawoi z punktu widzenia potrzeb narciarstwa. Sprawozdania Poznańskiego Towarzystwa Przyjaciót Nauk 2(90): 53-55.

Chomicz K., 1953. O pokrywie śnieżnej w Karpatach. Przegląd Meteorologiczny i Hydrologiczny VI(1-2): 16-29.

Chrustek P., Kolecka N., Bühler Y., 2013. Obtaining Snow Avalanche Information by Means of Terrestrial Photogrammetry - Evaluation of a New Approach. In: Kozak J., Ostapowicz K., Bytnerowicz A., Wyżga B. (eds) The Carpathians: Integrating Nature and Society Towards Sustainability. Environmental Science and Engineering. Springer, Berlin, Heidelberg.

Chrzanowski J., 1988. Pokrywa śnieżna w Polsce, klasyfikacja jej grubości i regionalizacja. Materiały Badawcze IMGW, seria: Meteorologia 15, Warszawa.

Chrzanowski J., 1989. Pokrywa śnieżna w Warszawie i próba jej prognozowania, Materiały Badawcze IMGW, seria: Meteorologia 16, Warszawa.

Cichała-Kamrowska K., Błaś M., Sobik M., Polkowska Z., Namieśnik J., 2011. Snow cover studies: A review on the intensity of human pressure. Polish Journal of Environmental Studies 20(4): 815-833.

Czajka B., Łajczak A., Kaczka R.J., 2015. The influence of snow avalanches on the timberline in the Babia Gora massif, Western Carpathians. Geographia Polonica 88(2): 147-161.

Czarnecka M. 1986. Struktura czasowa pokrywy śnieżnej na Pomorzu. Przegląd Geofizyczny 31(1): 67-76.

Czarnecka M., 2011. Zmienność terminów początku i końca pokrywy śnieżnej o różnym czasie zalegania i ich 
uwarunkowania cyrkulacyjne. Prace i Studia Geograficzne 47: 109-118.

Czarnecka M., 2012. Częstość występowania i grubość pokrywy śnieżnej w Polsce. Acta Agrophysica 19(3): 501-514.

Czyżewski M., 1929. Kilka spostrzeżeń nad grubością szaty śnieżnej w okolicy Lwowa. Czasopismo Geograficzne VII: 96-110.

Dobrowolski A.B., 1923a. Szata śnieżna - właściwości fizyczne. In: Dobrowolski A.B., Historja naturalna lodu, Wydawnictwo Kasy Pomocy dla Osób Pracujących na Polu Naukowem im. J. Mianowskiego, Warszawa: 411-488.

Dobrowolski A.B., 1923b. Szata śnieżna - strona opisowa, In: Dobrowolski A.B., Historja naturalna lodu, Wydawnictwo Kasy Pomocy dla Osób Pracujących na Polu Naukowem im. J. Mianowskiego, Warszawa: 489-635.

Dolnicki P., 2002. Wpływ pokrywy śnieżnej na termikę i grubość warstwy czynnej zmarzliny $\mathrm{w}$ obszarze tundrowym rejonu polskiej stacji polarnej w Hornsundzie (SW Spitsbergen). Problemy Klimatologii Polarnej 12: 107116.

Dylewska W., 1961. Grubość pokrywy śnieżnej i czas jej trwania na obszarach NW Pojezierza Mazurskiego, Podlasia, Mazowsza i Wyżyny Lubelskiej. Gazeta Obserwatora PIHM 14, 1(157): 9-11.

Dylewska W., 1964. Zawieje i zamiecie śnieżne w Polsce. cz. I, Biuletyn PIHM 7: 42-54

Falarz M., 1998. Wieloletnia zmienność pokrywy śnieżnej w Krakowie na tle zmian w obszarach podmiejskich. Acta Universitatis Lodziensis. Folia Geographica Physica 3: 473481.

Falarz M., 2000-2001. Zmienność wieloletnia występowania pokrywy śnieżnej w polskich Tatrach. Folia Geographica, Series Geographica Physica XXXI-XXXII: 101-123.

Falarz M., 2002a. Klimatyczne przyczyny zmian i wieloletniej zmienności występowania pokrywy śnieżnej w polskich Tatrach. Przeglad Geograficzny 74(1): 93-118.

Falarz M., 2002b. Long-term variability in reconstructed and observed snow cover over the last 100 winter seasons in Cracow and Zakopane (southern Poland). Climate Research 19(3): 247-256.

Falarz M., 2003. Changements et variabilite de la duree de la persistance et de l'epaisseur du couche de neige en Pologne au XX siecle. Dokumentacja Geograficzna 29: 108-112.

Falarz M., 2004. Variability and trends in the duration and depth of snow cover in Poland in the $20^{\text {th }}$ century. International Journal of Climatology 24(13): 1713-1727. DOI: 10.1002/joc.1093.

Falarz M., 2007a. Pokrywa śnieżna, In: D. Matuszko (red.), Klimat Krakowa w XX wieku, IGiGP UJ, Kraków: 139-147.

Falarz M., 2007b. Snow cover variability in Poland in relation to the macro- and mesoscale atmospheric circulation in the twentieth century. International Journal of Climatology 27(15): 2069-2081. DOI: 10.1002/joc.1505.

Falarz M., 2007c. Potencjalny okres występowania pokrywy śnieżnej w Polsce i jego zmiany w XX wieku. In: K. Piotrowicz, R. Twardosz (eds.), Wahania klimatu w różnych skalach przestrzennych $i$ czasowych, IGiGP UJ, Kraków: 205-213.

Falarz M., 2008. Changes of extreme nival conditions in Poland during the second half of the $20^{\text {th }}$ century. Meteorologische Zeitschrift 17(3): 339-444.

Falarz M., 2009. Variability of Icelandic Low and Azores High in winter and their influence on climatic conditions in Poland, Bulletin of Geography - Physical Geography Series 2: 9-23.
Falarz M., 2010. Współczynnik trwałości pokrywy śnieżnej w Polsce - rozkład przestrzenny, ekstrema, zmiany wieloletnie. In: E. Bednorz (ed.), Klimat Polski na tle klimatu Europy - warunki termiczne i opadowe, Seria: Studia i Prace z Geografii i Geologii, Bogucki Wydawnictwo Naukowe, Poznań: 169-180.

Falarz M., 2013. Seasonal stability of snow cover in Poland in relation to the atmospheric circulation. Theoretical and Applied Climatology 111(1-2): 21-28. DOI: 10.1007/ s00704-012-0642-x.

Falarz M., Faško P. Lapin M., 1998. Long-term variability of the snow cover in the Western Carpathians. In: Proceedings of the $2^{\text {nd }}$ European Conference on Applied Climatology, ECAC 98, 19 to 23 October 1998, Vienna, Austria, Oesterreichische Beitrage zu Meteorologie und Geophysik. Zentralanstalt fur Meteorologie und Geodynamik, 384(19): 19. Wien 1998, full text on "ECAC CD-ROM”, session 1: 1-6.

Falarz M., Marsz A.A., 2005. Wpływ zmian temperatury powierzchni Atlantyku Północnego na czas zalegania pokrywy śnieżnej w Polsce, Przeglad Geofizyczny 50(1-2): 13-29; errata: 51(1): 83-85.

Feleksy-Bielak M. 1978. Próba znalezienia związków pomiędzy opadem śniegu a wyglądem chmur na zdjęciach satelitarnych $\mathrm{w}$ podczerwieni. Wiadomości IMGW, IV (XXV) 1: 53-58.

Gądek B., 2014. Climatic sensitivity of the non-glaciated mountains cryosphere (Tatra Mts., Poland and Slovakia). Global and Planetary Change 121: 1-8.

Gądek B., Grabiec M., Rączkowska Z., Maciata A., 2016. Variability of the snow avalanche danger in the Tatra Mountains during the past nine decades, Geographia Polonica 89(1): 65-77.

Gądek B., Kędzia S., 2006. Reżim termiczny gruntu u spodu pokrywy śnieżnej $\mathrm{w}$ strefie wieloletniej zmarzliny $\mathrm{w}$ Tatrach. In: A. Kotarba, W. Borowiec (eds.), Tatrzański Park Narodowy na tle innych górskich terenów chronionych. T.1. Nauki o Ziemi. Wydaw. Tatrzańskiego Parku Narodowego, Zakopane-Kraków: 109-115.

Gądek B., Kędzia S., 2009. Problemy detekcji wieloletniej zmarzliny na podstawie temperatury u spagu zimowej pokrywy śnieżnej na przykładzie Tatr. Przegląd Geograficzny 81(1): 75-91.

Gądek B., Leszkiewicz J., 2010. Influence of snow cover on ground surface temperature in the zone of sporadic permafrost, Tatra Mountains, Poland and Slovakia. Cold Regions Science and Technology 60(3): 205-211. DOI: 10.1016/j.coldregions.2009.10.004.

Głowacki P., Pulina M., 2000. The physico-chemical properties of the snow cover of Spitsbergen (Svalbard) based on investigations during the winter season 1990/1991. Polish Polar Research 21(2): 65-88.

Gonera P., Rachlewicz G., 1997. Snow cover in the vicinity of Arctowski station, King George Island, in winter 1991. Polish Polar Research 18(1): 3-14.

Grabiec M, 2005. An estimation of snow accumulation on Svalbard glaciers on the basis of standard weather-station observations. Annals of Glaciology 42: 269-276.

Grabiec M., Leszkiewicz, J., Głowacki P., Jania J. 2006. Distribution of snow accumulation on some glaciers of Svalbard. Polish Polar Research 27(4): 309-326.

Gula R., 2004. Influence of snow cover on wolf Canis lupus predation patterns in Bieszczady Mountains, Poland. Wildlife Biology 10(1): 17-23. 
Gumiński R., 1931. Zima roku 1928/29 w Polsce. Przegląd Geograficzny XI: 119-127.

Gumiński R., 1947. Szata śnieżna. Wiad. Koresp. Rolnego GUS X, 12(10): 3-4.

Heino R., Tuomenvirta H., Vuglinsky V. S., Gustafsson B. G., Alexandersson H., Bärring L., Briede A., Cappelen J., Chen D., Falarz M., Førland E. J., Haapala J., Jaagus J., Kitaev L., Kont A., Kuusisto E., Lindström G., Meier H. E. M., Miętus M., Moberg A., Myrberg K., Niedźwiedź T., Nordli Ø., Omstedt A., Orviku K., Pruszak Z., Rimkus E., Russak V., Shrum C., Suursaar Ü., Vihma T., Weisse R., Wibig J., 2008. Past and Current Climate Change, In: The BACC Author Team, Assessment of Climate Change for the Baltic Sea Basin. Springer-Verlag, Berlin Heidelberg: 35-131.

Hess M., 1962. Wpływ pokrywy śnieżnej i lodowej na bilans promieniowania i mikroklimat gór, Zeszyty Naukowe UJ 47, Prace IG 2: 1-159.

Hess M., 1965. Pokrywa śnieżna, In: M. Hess, Piętra klimatyczne w polskich Karpatach Zachodnich, Zeszyty Naukowe UJ, Prace Geograficzne, 11: 157-172.

Hess M., 1968. Metoda określenia ilościowego zróżnicowania mezoklimatycznego w terenach górskich. Prace Geograficzne UJ 18: 7-26.

Jędrzejewski W., Jędrzejewska B., Okarma H., Ruprecht A.L., 1992. Wolf predation and snow cover as mortality factors in the ungulate community of the Białowieża National Park, Poland. Oecologia 90(1): 27-36. DOI: 10.1007/ BF00317805.

Juraszek-Wiewióra K., 2005. Zarys historii badań pokrywy śnieżnej w Tatrach Polskich. Czas. Geogr. 76(3): 215-234.

Jurzecki S., 1969. Wpływ pogody i klimatu na wegetację roślin uprawnych w pogórskim odcinku Raby. Prace Geograficzne UJ 25: 117-130.

Kamińska E.W., 1912. Trwałość szaty śnieżnej na północnym stoku Karpat. Rozprawy Wydziału Matematyczno-Przyrodniczego Akademii Umiejętności, ser. III, 12: 317-344.

Kanzaki N., Perzanowski K., Nowosad M., 1998: Factors affecting wild boar (Sus scrofa) population dynamics in Bieszczady, Poland. Gibier Faune Sauvage, Game Wildl., 15: 1171-1178.

Karzyński M., Nodzyński T., 2005. Śnieg i lawiny w Tatrach Polskich w erze informatyzacji. In: I. Sawicka (red.) $\mathrm{Hy}$ drologia, meteorologia, klimatologia - badania naukowe $i$ prognozy w erze informatyzacji. Seria: Monografie IMGW, $107-113$.

Kasina M., 2008. Zróżnicowanie chemizmu pokrywy śnieżnej na obszarze między górnośląskim okręgiem przemysłowym a Krakowem, Prace Geograficzne, 120: 51-64.

Kasprowicz T., 2010. Prawidłowości przestrzenne występowania pokrywy śnieżnej Polsce i próba ich regionalizacji. In: E. Bednorz (ed.), Klimat Polski na tle klimatu Europy. Warunki termiczne i opadowe, seria: Studia i Prace z Geografii i Geologii, 15, Bogucki Wydawnictwo Naukowe, Poznań, 181-198.

Kędzia S., 1999. Badania nad rozkładem temperatury w pokrywie śnieżnej i w gruncie w Polskiej części Tatr. Czasopismo Geograficzne LXX: 93-101.

Kępski D., Luks B., Migała K., Wawrzyniak T., Westermann S. and Wojtun B., 2017. Terrestrial Remote Sensing of Snowmelt in a Diverse High-Arctic Tundra Environment Using Time-Lapse Imagery. Remote Sensing 9(733): 1-22.

Klein J., 1967. Powiązanie między pokrywą śnieżną a zbiorowiskami roślinnymi w Ojcowskim Parku Naro- dowym. Fragmenta Floristica et Geobotanica Polonica XIII, 1: 77-100.

Kłapa M., 1968. Procesy i formy ablacji pokrywy śnieżnej w Wysokich Tatrach. Studia Geomorphologica Carpatho-Balcanica 2(11): 115-123.

Kłapa M., 1980. Procesy morfogenetyczne i ich związek z sezonowymi zmianami pogody w otoczeniu Hali Gąsienicowej w Tatrach. Dokumentacja Geograficzna 4.

Kłapowa M., 1980a. Charakterystyka temperatury w pokrywie śnieżnej w Tatrach, Wiadomości IMGW VI(XXVII), 1-2: 75-80.

Kłapowa M., 1980b. Metamorfoza śniegu w zależności od warunków atmosferycznych i rzeźby terenu w Tatrach, Materiaty Badawcze IMGW, seria: Meteorologia.

Kłapowie M.M., 1967. Wstępne wyniki pomiaru parowania i topnienia śniegu w Tatrach. Czasopismo Geograficzne XXXVIII (2): 183-192.

Kosiba A. 1948/1949. Problem zaśnieżenia ziem Śląskich w zależności od warunków hipsometrycznych. Przeglą Geograficzny XXII: 157-163.

Kosiba, A., 1949. Częstość szaty śnieżnej na ziemiach Śląskich. Prace Wrocławskiego Towarzystwa Naukowego, Ser. B 21.

Kosiba A., 1954. The snowfall in Silesia. Acta Geophysica Polonica II, 3: 136-139.

Kosiba A., 1957. Badania nad warunkami śnieżnymi w Karkonoszach. Sprawozdania Wroctawskiego Towarzystwa Naukowego 12(B): 18-19.

Kosińska-Bartnicka S., 1925. Uśnieżenie w Polsce zimą 1923/4. Czasopismo Geograficzne III (1/2): 72-76.

Kosińska-Bartnicka S., 1924. Uśnieżenie w Polsce zimą 1922/23. Czasopismo Geograficzne II (3/4): 393-406.

Kotarba A., 2017. Śnieg w Polsce - obserwacje satelitarne. Online: zoz.cbk.waw.pl/snieg/ (accessed 30 September 2017).

Kozłowska A., Rączkowska Z., 2006. Effect of snow patches on vegetation in the high-mountain nival gullies (Tatra Mts. Poland). Polish Journal of Ecology 54(1): 69-90.

Kozłowski R., Jarzyna K., Jóźwiak M., Szwed M., 2012. Wpływ przemysłu cementowo-wapienniczego na właściwości fizyczno-chemiczne i chemiczne pokrywy śnieżnej na terenie „Białego Zagłębia”, Monitoring Środowiska Przyrodniczego 13: 71-80.

Kozyra J., 2005. Metoda Konstrukcji cyfrowych map występowania pokrywy śnieżnej w Polsce. In: I. Sawicka (ed.) Hydrologia, meteorologia, klimatologia - badania naukowe i prognozy w erze informatyzacji. Seria: Monografie IMGW: 114-121.

Krzesiwo K., 2015. Rozwój turystyki narciarskiej w świetle idei zrównoważonego rozwoju - stan badań. Prace Geograficzne UJ 141: 117-140.

Kupczyk E., 1997. Akumulacja i topnienie pokrywy śnieżnej. In: U. Soczyńska (ed.), Hydrologia dynamiczna, Wydawnictwo Naukowe PWN, Warszawa: 122-138.

Kwiatkowski J., 1978. Pokrywa śnieżna Sudetów, jej gęstość i zawarty w niej zapas wody. Czasopismo Geograficzne XLIX: 419-435;

Kwiatkowski J., 1983. Śniegowo-narciarskie warunki w Sudetach. Acta Universitatis Wratislaviensis, 506, Studia Geograficzne 32: 139-153.

Kwiatkowski J., Lucerski P., 1979a. Pokrywa śnieżna regionu Kotliny Kłodzkiej jako warunek rozwoju sportów zimowych rekreacji i turystyki. Problemy Zagospodarowania Ziem Górskich 20: 33-56. 
Kwiatkowski J., Lucerski. P., 1979b. Warunki śniegowe i narciarskie na północnych stokach Karkonoszy. Opera Corcontica 16: 51-71.

Laska M., Luks B., Budzik T., 2016. Influence of snowpack internal structure on snow metamorphism and melting intensity on Hansbreen, Svalbard. Polish Polar Research 37(2): 193-218.

Lempa M., Kaczka R. J., Rączkowska Z. 2014. Rekonstrukcja aktywności lawin śnieżnych w Białym Żlebie (Tatry Wysokie) na podstawie przyrostów rocznych świerka pospolitego (Picea abies L. Karst.). Studia i Materiaty CEPL, 40: 105-112.

Lempa M., Kaczka R.J., Rączkowska Z., Janecka K., 2016, Combining tree-ring dating and geomorphological analyses in the reconstruction of spatial patterns of the runout zone of snow avalanches, Rybi Potok Valley, Tatra Mountains (Poland). Geographia Polonica 89(1): 31-45.

Lenart W., Nowicki W., 1984. Chemizm pokrywy śnieżnej jako test rozprzestrzeniania się zanieczyszczeń powietrza. Przeglad Geofizyczny XXIX (2): 171-179.

Leszczycki S., 1931. Współczesny stan badań niwalnych w Polsce. Wiadomości Geograficzne IX (3): 31-34.

Leszkiewicz J., Pulina M., 1999. Snowfall phases in analysis of a snow cover in Hornsund, Spitsbergen. Polish Polar Research 20(1): 3-24.

Leśniak B., 1973. O niektórych charakterystykach pokrywy śnieżnej w Woj. Krakowskim. Prace Geograficzne UJ 32(54): 119-128.

Leśniak B., 1980. Pokrywa śnieżna w dorzeczu górnej Wisły. Prace Geograficzne UJ 51: 75-127.

Leśniak B., 1981. Współczynnik trwałości pokrywy śnieżnej na obszarze dorzecza górnej Wisły. Geographica, Series Geographia Physica 14: 89-102.

Leśniak B., 1986, Wpływ opadów w postaci stałej i temperatury powietrza na częstość występowania dni z pokrywą śnieżną w Karpatach Zachodnich. Prace Geograficzne UJ 67: 69-79.

Lewińska J., 1963. Zasoby wodne śniegu w dorzeczu Dunajca i metoda ich określania. Prace PIHM 78: 3-45.

Lorenc H., 1964. Zaśnieżenie Wielkopolski. Gazeta Obserwatora PIHM. 17(4): 8-9.

Luks B., Osuch M., Romanowicz R.J, 2011. The relationship between snowpack dynamics and $\mathrm{NAO} / \mathrm{AO}$ indices in SW Spitsbergen. Physics and Chemistry of the Earth, Parts A/B/C 36(13): 646-654.

Łajczak A., 2006. Modelowanie stoków górskich pod wpływem narciarstwa na przykładzie otoczenia Hali Miziowej na północnym stoku Pilska, Beskid Żywiecki. In: A. Kostrzewski, J. Czerniawska (eds.) Przemiany środowiska geograficznego Polski pótnocno-zachodniej. Wydział Nauk Geograficznych i Geologicznych UAM, Poznań, 219-227.

Łobożewicz T., 1970. Klasyfikacja powierzchni warstwy śniegu narciarskiej trasy biegowej. Sport Wyczynowy VIII (2): 30-32.

Łobożewicz T., 1979. Warunki rozwoju turystyki i sportu narciarskiego w Polsce w świetle badań śniegowych. Instytut Turystyki, Warszawa.

Łopata H., Warakomski W., 1977. O występowaniu zamieci i zawiei śnieżnych w Polsce w latach 1954/55-1963/64. Folia Societatis Scientiarum Lublinesis 19, Geografia (2): 69-73.

Madany R., 1961. O opadach śniegu i szacie śnieżnej w Karpatach Polskich w okresie 1951-1955. Przeglad Geofizyczny 6(14), 3: 131-146.

Merecki R., 1914. Klimatologia Ziem Polskich. Warszawa.
Michałowski M., 1962. Wpływ pokrywy śnieżnej na warunki zimowania roślin. Rolnik Lubelski 1: 25-26.

Michna E., Paczos S., 1971a. Die Schneebedingungen des westlichen Bieszczady-Gebirge in Anbetracht touristischer und wintersportlicher Anforderungen. Folia Societatis Scientiarum Lublinesis sec. D 11: 3-7.

Michna E., Paczos S., 1971b. O warunkach śniegowych Roztocza w świetle potrzeb turystyki i sportów zimowych. Folia Societatis Scientiarum Lublinesis sec. D 12: 7-13.

Michna E., Paczos S., 1976. Climatological criteria for the evaluation of snow conditions for the purpose recreation and wintersport with south-eastern Poland as an example. Geographia Polonica 33: 121-134.

Michna E., Paczos S., 1978. Warunki śniegowe Polski Południowo-Wschodniej. Biuletyn Lubelskiego Towarzystwa Naukowego, Geografia 1: 7-14.

Milata W., 1937a. Narciarskie pogodoznawstwo. In: Informacyjny Kalendarz Narciarski na sezon 1937/1938, Wyd. PZN Kraków: 98-113.

Milata W., 1937b. Pokrywa śnieżna w Karpatach. Prace Studium Turyzmu Uniwersytetu Jagiellońskiego w Krakowie, III.

Milata W., 1938. Karpacka Komisja Śniegowa i Lawinowa w Krakowie. Wierchy XVI: 184-185.

Milata W., 1947. Lawiny. Wierchy. XVII: 175-179.

Molga M., 1949. O niektórych zimowych obserwacjach rolniczo-meteorologicznych. Wiad. Koresp. Rolnego GUS 11, 1(123): 3-5.

Mrugała S., 1987. Typy cyrkulacji i masy powietrza a występowanie odwilży atmosferycznych w Polsce. Annales UMCS 42/43, sec. B: 173-187.

Myczkowski S., 1956. Lawina a las tatrzański. Wierchy XXV: 198-201.

Myczkowski S., 1962. Wpływ lawin śnieżnych na lasy TPN w dolinach Rybiego Potoku, Roztoki, Waksmundzkiej i Pańszczycy. Ochrona Przyrody 28: 83-108.

Nawrot A.P., Migała K., Luks B., Pakszys P., Głowacki P., 2016. Chemistry of snow cover and acidic snowfall during a season with a high level of air pollution on the Hans Glacier, Spitsbergen. Polar Science 10(3): 249-261. DOI: 10.1016/j.polar.2016.06.003.

Niedźwiedź T., 1981. Sytuacje synoptyczne $i$ ich wptyw na zróżnicowanie przestrzenne wybranych elementów klimatu $w$ dorzeczu górnej Wisty. Rozprawy Habilitacyjne UJ, 58, Wyd. UJ, Kraków.

Niedźwiedź T., Styszyńska A., 2013. Snow cover at the Hornsund station. In: A. Marsz, A. Styszyńska (eds.), Climate and climate change at Hornsund, Svalbard, Maritime University, Gdynia: 367-372.

Nowosad M., 1980. Ocena wybranych elementów meteorologicznych pod kątem potrzeb turystyki narciarskiej na przykładzie Przemyśla. Folia Societatis Scientiarum Lublinesis 22, Geografia 2: 63-68.

Nowosad M., 1980/1981. Sezony narciarskie w Komańczy (1960/61-1974/75). Annales UMCS sec. B., XXXV/XXXVI: 161-173.

Nowosad M., 1992. The Dynamics of Snow Depth Depending on the Types of Atmospheric Circulation on the Example of the Bieszczady Mountains. UMCS, Lublin.

Nowosad M., 1993a: Dependence of Change of Snow Depth on Snowfalls at Brzegi Dolne. In: A. Becker, B. Sevruk, M. Lapin (eds.) Proceeding of the International Symposium on Precipitation and Evaporation, 3, Evaporation, Water Balance \& Deposition, Bratislava: 329-334.

Nowosad M., 1993b: Wpływ deszczu na pokrywę śnieżną na przykładzie posterunku Brzegi Dolne. 42. Zjazd Polsk- 
iego Towarzystwa Geograficznego. Polskie Towarzystwo Geograficzne - Oddziat w Kielcach, WSP, Kielce: 92-93.

Nowosad M., 1994. Zarys charakterystyki pokrywy śnieżnej w Bieszczadach. Annales UMCS, sec. B, XLIXL: 197-215.

Nowosad M., Bartoszek K., 2007. Wieloletnia zmienność grubości pokrywy śnieżnej w okolicy Lublina. In: K. Piotrowicz, R. Twardosz (eds.) Wahania klimatu w różnych skalach przestrzennych i czasowych. IGiGP UJ, Kraków: 411-421.

Ociepa E., Mrowiec M., Deska I., Okoniewska E., 2015. Pokrywa śnieżna jako ośrodek depozycji zanieczyszczeń. Rocznik Ochrona Srodowiska 17(1): 560-575.

Okarma H., Jędrzejewska B., Jędrzejewski W., Krasinski Z.A., Milkowski L., 1995. The roles of predation, snow cover, acorn crop, and man-related factors on ungulate mortality in Bialowieza Primeval Forest, Poland. Acta Theriologica 40(2): 197-217.

Ormicki M., 1929. Przyczynek do morfologji szaty śnieżniej. Przeglad Geograficzny IX, 183-196.

Paczos S., 1977. Pokrywa śnieżna w województwie rzeszowskim ze szczególnym uwzględnieniem obszarów górskich. In: Śnieg i pokrywa śnieżna - Materiały z Sympozjum w Zakopanem 15-17.03.1973, Materiały Badawcze IMGW, ser. Meteorologia: 97-121.

Paczos S., 1982. Stosunki termiczne i śnieżne zim w Polsce. Wydawnictwo Uniwersytetu Marii Curie-Skłodowskiej, Lublin.

Paczos S., 1985. Pokrywa śnieżna w Polsce. Annales UMCS sectio B, XL (5): 78-104.

Piotrowicz K., 1996. Variability of the number of days with snowfall and days with snow cover against the background of air temperature changes in winter in Cracow, In: B. Obrębska-Starkel, T. Niedźwiedź (eds.), Proceedings of the international conference on climate dynamics and the global change perspective, Cracow, October 17-20 1995, Zesz. Nauk. UJ, Pr. Geogr. 102: 435-440.

Polkowska Z., Demkowska I., Cichała-Kamrowska K., Namieśnik J., 2010. Pollutants present in snow samples collected from various layers of snow cover as a source of information about the state of environment in a big urban agglomeration. Ecological Chemistry and Engineering 17(2): 203-231.

Przybylak R., 2003. Atmospheric Precipitation and Snow Cover. In: R. Przybylak (ed.), Climate of the Arctic, $2^{\text {nd }}$ edition. Book Series: Atmospheric and Oceanographic Sciences Library, 52: 137-164. DOI: 10.1007/978-3-319-21696-6_7.

Rajca T., 1964. Kolejowa stużba drogowa w walce ze śniegiem $i$ mrozem. WKiŁ, Warszawa.

Rajwa A., 1965. Kształtowanie się gęstości śniegu na Kasprowym Wierchu w 1959/1960 r. Prace PIHM 87: 59-64.

Rasmus S., Boelhouwers J., Briede A., Brown I.A., Falarz M., Ingvander S., Jaagus J., Kitaev L., Mercer A., Rimkus E., 2015. Recent Change - Terrestrial Cryosphere. In: The BACC II Author Team, Second Assessment of Climate Change for the Baltic Sea Basin, ser. Regional Climate Studies, Springer, London: 117-129. DOI: 10.1007/978-3-31916006-1.

Rączkowska Z., Długosz M., Gądek B., Grabiec M., Kaczka R.J., Rojan E. 2015. Uwarunkowania przyrodnicze, skutki i zmiany aktywności lawin śnieżnych w Tatrach. In: A. Kotarba (ed.) Przyroda Tatrzańskiego Parku Narodowego a Człowiek, Tom I Nauki o Ziemi, Wydawnictwa Tatrzańskiego Parku Narodowego, Zakopane: 133-141.
Romer E., 1892. Powroty zimy. Wszechświat XI (27): 417-420; (28): 438-440.

Romer E., 1913. O wpływie lasów na klimat i wody gruntowe na podstawie doświadczeń w lasach dobrostańskich. Kosmos XXXVIII: 1573-1607.

Rostafiński J., 1927. O czerwonym i żółtym śniegu w Tatrach. Wierchy V: 10-11.

Sadowski M., 1980. Rozkład przestrzenny zapasu wody w pokrywie śnieżnej w Polsce. Materiały Badawcze IMGW, Hydrologia i Oceanologia: 3-119.

Sarna T., 2000. Charakterystyka warunków śniegowych i wyznaczanie okresów korzystnych do uprawiania narciarstwa biegowego i zjazdowego w Zakopanem. Prace Geograficzne UJ 105: 203-210.

Satke W., 1896. Ciepłota śniegu w zimie 1893/4 w Tarnopolu. Sprawozdania Komisji Fizjograficznej PAU 31: 248-255.

Satke W., 1899. Badania nad pokrywą śniegową w Tarnopolu. Kosmos, XXIV: 89-93; 183-216.

Siudek P., Frankowski M., Siepak J., 2015. Trace element distribution in the snow cover from an urban area in central Poland. Environmental Monitoring and Assessment 187 (5): 15. DOI: $10.1007 /$ s10661-015-4446-1.

Smoleński J., 1932. Z badań wysokogórskiej stacji naukowej w Dolinie Pięciu Stawów Polskich w Tatrach. Wierchy X: 151-156.

Sobota I., 2017. Selected problems of snow accumulation on glaciers during long-term studies in north-western Spitsbergen, Svalbard. Geografiska Annaler Series A-Physical Geography 99(2): 177-192. DOI: 10.1080/04353676.2017.1297679.

Spyt B., Kaczka R.J., Lempa M., Rączkowska Z., 2016. Application of timberline morphometric analysis for detecting snow avalanche paths: A case study of the Tatra Mountain. Geographia Polonica 89(1): 91-111.

Stachnik L., Uzarowicz L., 2011. The relationship between dissolved solids yield and the presence of snow cover in the Periglacial Basin of the Obruchev glacier (Polar Urals) during the ablation season. Quaestiones Geographicae 30(1): 95-103. DOI: 10.2478/v10117-011-0009-x.

Szkutnicki J., 1978. Parowanie i sublimacja z pokrywy śnieżnej na podstawie badań eksperymentalnych na Hali Gąsienicowej. Wiadomości IMGWIV(XXV) 4: 39-51.

Sztyler A., 1989. Elemental carbon concentration in air and its influence on attenuation of incoming solar radiation and snow cover albedo in Katowice, Southern Poland. Journal of Aerosol Science 20(8): 1193-1196.

Szwed M., Pińskwar I., Kundzewicz Z.W., Graczyk D., Mezghani A., 2017. Changes of snow cover in Poland. Acta Geophysica 65(1): 65-76. DOI: 10.1007/s11600-0170007-z.

Szwed M., Kundzewicz Z.W., Mezghani A., 2016. Variability of snow cover and frost depth at the Potsdam station, Germany. Geografie 121(4): 493-520.

Teisseyre A.K., 1979. Przebieg zjawisk fluwialnych w zimie na przykładzie małych rzek sudeckich. Geologica Sudeti$\mathrm{ca}, \mathrm{XIV}, 1$.

Trepińska J., 1973. Prawdopodobieństwo występowania pokrywy śnieżnej w Krakowie. Przegląd Geofizyczny. 18(1-2) 27-32.

Wróblewski W., 1893. Szata śnieżna i wpływ jej na glebę, klimat i pogodę. Wszechświat 7: 97-101. 8: 117-121.

Zapałowicz H., 1880. Roślinność Babiej Góry pod względem geograficzno-botanicznym. Sprawozdania Komisji Fizjograficznej PAU XIV(II): 79-237. 
Zapałowicz H., 1889. Roślinna szata gór Pokucko-Marmaroskich. Sprawozdania Komisji Fizjograficznej PAU XXIV, Kraków.

Zwoliński Zb., 2007. Mobilność materii mineralnej na obszarach paraglacjalnych, Wyspa Króla Jerzego, Antarktyka Zachodnia [The mobility of mineral matter in paraglacial areas, King George Island, Western Antarctica]. Adam Mickiewicz University Press, Poznań, Seria Geografia 74: 1-266.

Żarnowiecki G., 2008. Związki między pokrywą śnieżną a roślinnością na przykładzie grądów Białowieskiego Parku Narodowego. Prace Geograficzne IGiPZ PAN, 216. 